\title{
KEBERHASILAN DAN KOMPATIBILITAS PENYERBUKAN SENDIRI DAN SILANG PADA HIBRIDISASI INTERSPESFIK CIPLUKAN (Physalis spp)
}

\section{SELF- AND CROSS-POLLINATION SUCCESS RATES AND COMPATIBILITIES IN CIPLUKAN (Physalis spp) INTERSPECIFIC HYBRIDIZATION}

\author{
Zainyah Salmah Arruum, Budi Waluyo* \\ Jurusan Budidaya Pertanian, Fakultas Pertanian, Universitas Brawijaya \\ Jalan Veteran, Malang Jawa Timur, Indonesia 654145 \\ Korespondensi : budiwaluyo@ub.ac.id
}

Diterima : 24 Agustus 2020 / Disetujui : 19 Juli 2021

\begin{abstract}
ABSTRAK
Tanaman ciplukan digunakan untuk menghasilkan buah segar, bahan baku nutraceutical, dan biofarmasi. Kapasitas genetik ciplukan dapat ditingkatkan dengan hibridisasi interspesifik. Ketidakcocokan adalah masalah yang muncul pada persilangan antarspesies. Tujuan penelitian adalah untuk mempelajari keberhasilan dan kompatibilitas penyerbukan sendiri dan penyerbukan silang hibridisasi interspesifik ciplukan. Penelitian dilaksanakan di Seed and Nursery Industry, Agro Techno Park, Universitas Brawijaya pada bulan Januari sampai Juni 2020. Penelitian menggunakan bahan 5 spesies ciplukan, yaitu Physalis $P$. angulata, $P$. peruviana, $P$. pruinosa, $P$. pubescens, dan $P$. ixocarpa. Pola perkawinan dialel digunakan serta pengamatan terhadap hasil penyerbukan diamati. Hasil penyerbukan silang interspesifik memiliki derajat kompatibilitas yang berbeda. Kompatibilitas penyerbukan sendiri pada setiap spesies tinggi. Penyerbukan silang interspesifik P. pubescens (PPB-68154-04) × $P$. angulata (PAN-69281) kompatibel. Inkompatibilitas parsial terdapat pada penyerbukan silang interspesifik P. angulata (PAN-69281) x P. ixocarpa (PIX-4418-2), P. pubescens (PPB-68154-04) $\times$ P. ixocarpa (PIX-4418-2), P. pruinosa (PPN+3101) x P. angulata (PAN-69281), dan $P$. pruinosa $(\mathrm{PPN}+3101) \times P$. ixocarpa (PIX-4418-2). Inkompatibilitas lengkap terjadi pada penyerbukan silang $P$. angulata (PAN-69281) $\times P$. pubescens (PPB-68154-04), $P$. angulata (PAN-69281) $\times P$. pruinosa $(\mathrm{PPN}+3101), P$. pubescens (PPB-68154-04) $\times$ P. pruinosa $(\mathrm{PPN}+3101), P$. pruinosa (PPN+3101) $\times$ P. pubescens (PPB-68154-04), P. pruinosa (PPN+3101) x P. ixocarpa (PIX-4418-2), $P$. peruviana (PPV-45311-03) dan P. ixocarpa (PIX-4418-2). Penyerbukan sendiri dan penyerbukan silang yang kompatibel menghasilkan perbedaan pada karakteristik buah dan benih. P. pruinosa (PPN+3101), P. angulata (PAN-69281), dan P. pubescens (PPB-68154-04) menghasilkan jumlah benih yang berbeda pada penyerbukan silang interspesifik.
\end{abstract}

Kata kunci: ciplukan, inkompatibilitas, persilangan interspesifik, Physalis.

\begin{abstract}
Ciplukan is used as a fresh fruit, nutraceutical raw materials, and biopharmaceuticals. Genetic capacity of ciplukan can be increased by interspecific hybridization. Incompatibility is an issue obtained during the interspecific hybridization. Research objective was to study

Cite this as: Arrum, Z. S. \& Waluyo, B. (2021). Keberhasilan dan kompatibilitas penyerbukan sendiri dan silang pada hibridisasi interspesifik ciplukan (Physalis spp). Jurnal Agro, 8(1), 84-99.


success rate and compatibility of self-pollination and cross-pollination ciplukan interspecific hybridization. Research was conducted at Seed and Nursery Industry, Agro Techno Park, Universitas Brawijaya from January to June 2020. Physalis $P$. angulata, $P$. peruviana, $P$. pruinosa, $P$. pubescens, and $P$. ixocarpa were species included in this study. A diallel mating design pattern was used as well as observations of pollination. Interspecific cross pollination was found to have differing degrees of compatibility. Compatibility of self-pollination in each species is high. Interspecific cross-pollination of $P$. pubescens (PPB-68154-04) $\times$ P. angulata (PAN-69281) is compatible. Partial incompatibilities exist in interspecific cross-pollination of $P$. angulata (PAN-69281) x P. ixocarpa (PIX-4418-2), P. pubescens (PPB-68154-04) × P. ixocarpa (PIX-4418-2), $P$. pruinosa (PPN+3101) $\times$ P. angulata (PAN-69281), and P. pruinosa (PPN+3101) $\mathrm{x}$ $P$. ixocarpa (PIX-4418-2). Complete incompatibility occurred in cross-pollination of $P$. angulata (PAN-69281) X P. pubescens (PPB-68154-04), P. angulata (PAN-69281) × $P$. pruinosa (PPN+3101), P. pubescens (PPB-68154-04) x P. pruinosa (PPN+3101), P. pruinosa (PPN+3101) $\mathrm{x}$ P. pubescens (PPB-68154-04), P. pruinosa (PPN+3101) x P. ixocarpa (PIX-4418-2), P. peruviana (PPV-45311-03) and $P$. ixocarpa (PIX-4418-2). Compatible self-pollination and cross-pollination resulted differences in fruit and seed characteristics. P. pruinosa (PPN+3101), P. angulata (PAN-69281), and P. pubescens (PPB-68154-04) developed different numbers of seeds following interspecific cross-pollination.

Keywords: ciplukan, incompatibility, interspecific crosses, Physalis

\section{PENDAHULUAN}

Tanaman Physalis banyak tersebar di dunia dan awalnya sering dimanfaatkan untuk pengobatan tradisional. Terdapat sekitar 120 spesies Physalis di dunia, yang dibedakan berdasarkan karakter morfologi tanaman maupun ada tidaknya rambut pada batang (Sharma et al., 2015). Tanaman Physalis tersebar di berbagai macam negara tropis dan subtropis seperti daerah tropis Amerika dan Eropa serta di Asia (Yildiz et al., 2015). Physalis merupakan buah eksotis yang mengandung banyak senyawa kimia bermanfaat dan mulai dikembangkan oleh banyak negara di dunia (Rodrigues et al., 2009). Banyak negara yang telah melakukan budidaya secara komersial seperti Kolombia, Brazil, Meksiko, India, Mediterania, serta Afrika Selatan (Muniz et al., 2014).

Tanaman Physalis selain dijadikan sebagai tanaman sumber buah juga digunakan sebagai bahan obat tradisional. Masyarakat di beberapa negara seperti
Kolombia, China, Bolivia, dan Nigeria memanfaatkan Physalis untuk pengobatan kanker, Iran memanfaatkan tanaman ini untuk pengobatan asma, disfungsi hati, dan bahan obat penyakit cacing, Peru dan Brasil memanfaatkan tanaman ini sebagai obat malaria, infeksi post-partum dan gatal-gatal, masyarakat Bangladesh memanfaatkan tanaman Physalis untuk mengatasi infeksi kulit, sedangkan di Indonesia tanaman ini digunakan untuk mengatasi hepatitis dan nyeri otot (Jovel et al., 1996; Rodrigues, 2006; Abubakar et al., 2007; He et al., 2007; Salgado dan Arana, 2014; Mirzaee et al., 2019).

Seiring dengan berkembangnya
agroindustri berbasis nutraseutikal,
farmaseutikal, dan pangan maka Physalis mempunyai potensi untuk dikembangkan sebagai bahan baku agroindustri yang harus tersedia secara kontinyu baik kuantitas maupun kualitas. Saat ini belum ada pengembangan tanaman ciplukan yang khusus dilakukan untuk penyediaan bahan 
baku industri (Waluyo et al., 2019; Zanetta et al., 2019). Selama ini bahan baku baru dipenuhi melalui eksploitasi ciplukan yang tumbuh liar yang dan kualitasnya terbatas. Saat ini belum ada jaminan ketersediaan bahan baku Physalis secara kontinyu untuk bahan baku agroindustri. Oleh karena itu perlu dilakukan upaya peningkatan kapasitas genetik tanaman ciplukan agar sesuai dengan kebutuhan industri melalui kegiatan pemuliaan tanaman sehingga menjamin ketersediaan bahan baku, lebih bernilai secara ekonomis, dan diinginkan secara agronomis. Upaya peningkatan kualitas penampilan tanaman ciplukan dapat dilakukan melalui pemuliaan tanaman melalui kegiatan persilangan. Persilangan dapat dilakukan pada tanaman dengan spesies sama (intraspesifik) maupun pada spesies yang berbeda (interspesifik) (Setiawati et al., 2016). Persilangan tetua dengan melibatkan latar belakang genetik yang luas biasanya akan menghasilkan keturunan yang superior (Jansky \& Rouse, 2003; Siemens, 2002). Pada persilangan interspesifik, inkompatibilitas menjadi kendala dalam pembentukan buah dan biji (Frankel \& Galun, 1977). Inkompatibilitas merupakan ketidakcocokan gen atau kromosom suatu tanaman dalam berpasangan sehingga menyebabkan terjadinya kegagalan pembuahan (Frankel \& Galun, 1977).

Perkembangbiakan ciplukan terjadi secara reproduktif melalui biji. Tanaman ciplukan memiliki bunga sempurna dengan organ jantan dan betina ada dalam satu bunga. Biji yang terbentuk adalah hasil penyerbukan yang terjadi dengan serbuk sari jatuh di atas kepala putik pada bunga sendiri dibantu oleh angin, atau dibantu oleh serangga yang hinggap pada bunga (Djakbé et al., 2017; Peña-Lomelí et al.,
2018). Beberapa penelitian melaporkan Physalis mempunyai sistem reproduksi menyerbuk sendiri, walaupun dilaporkan adanya inkompatibilitas sendiri dan inkompatibilitas silang (Chautá-Mellizo et al., 2012; Djakbé et al., 2017; Figueiredo et al., 2020; Peña-Lomelí et al., 2018; Trevisani et al., 2016). Penyerbukan silang pada ciplukan dapat mencapai 54\% (Lagos et al., 2008). Rekombinasi genetik melalui persilangan buatan antar spesies dapat menghasilkan keturunan yang superior yang dapat memenuhi kriteria sesuai dengan kebutuhan industri atau dapat juga menghasilkan spesies baru (Azeez \& Faluyi, 2018; Olorode et al., 2013). Sejauh ini di Indonesia belum ada laporan tentang upaya perbaikan genetik ciplukan melalui persilangan. Peneliti pemulia tanaman di Universitas Brawijaya telah melakukan penelitian terhadap keragaman dan pemilihan bahan genetik $P$. angulata, $P$. peruviana, $P$. pubescens, $P$. pruinosa dan $P$. ixocarpa yang potensial ditingkatkan kapasitas genetiknya melalui rekombinasi genetik interspesifik dengan harapan menghasilkan kultivar unggul untuk kebutuhan agroindustri (Effendy et al., 2018; Rukmi \& Waluyo, 2019; Sadiyah et al., 2020, 2021; Shandila et al., 2019; Waluyo et al., 2019; Widyaelina \& Waluyo, 2019; Zanetta et al., 2019).

Persilangan antar spesies pada Physalis akan berhasil dan dihasilkan keturunan jika diperoleh informasi tentang tingkat keberhasilan dan kompatibilitas dari penyerbukan yang dilakukan. Tujuan penelitian ini adalah untuk mengetahui tingkat keberhasilan penyerbukan sendiri dan kompatibilitas pada penyerbukan silang hibridisasi interspesifik pada ciplukan spesies $P$. angulata, $P$. peruviana, $P$. pubescens, $P$. pruinosa dan $P$. ixocarpa. 


\section{BAHAN DAN METODE}

Penelitian ini dilaksanakan pada bulan Januari hingga Juni 2020 di Seed dan Nursery Industry Agro Techno Park Universitas Brawijaya. Bahan tanam yang digunakan adalah 5 spesies ciplukan yaitu $P$. angulata (PAN-69281), $P$. pruinosa (PPN+3101), P. peruviana (PPV-45311-03), $P$. pubescens (PPB-68154-04), dan $P$. ixocarpa (PIX-4418-2).

Pasangan persilangan disusun berdasarkan rancangan perkawinan dialel lengkap yaitu terdapat set penyerbukan sendiri, set persilangan untuk menghasilkan biji $\mathrm{F} 1$, dan set persilangan untuk F1 resiprok. Penyerbukan buatan dilakukan dengan metode tangan (hand pollination) dibantu alat pinset untuk emaskulasi dan menempelkan serbuk sari ke atas kepala putik. Terdapat 25 kombinasi persilangan. Setiap spesies terdiri dari 12 tanaman yang ditanam secara berkala untuk sinkronisasi munculnya bunga sebagai tetua betina dan tetua jantan untuk bahan persilangan. Penanaman ciplukan tiap spesies dibagi menjadi 2 periode dengan jeda waktu 10 hari. Tanaman ciplukan ditanam dengan jarak tanam $50 \times 80 \mathrm{~cm}$. Kegiatan persilangan dilakukan pada pagi hari berkisar jam 07.00-12.00, pada sore hari melakukan kegiatan emaskulasi dan kastrasi pada bunga yang dijadikan tetua betina.

Dilakukan observasi pada morfologi bunga ciplukan dan tingkat kompatibilitas persilangan yang dilihat dari keberhasilan penyerbukan pada tiap set persilangan yang dilakukan. Karakteristik buah dan biji hasil penyerbukan sendiri dan hasil persilangan dianalisis menggunakan uji $\mathrm{t}$ $5 \%$.
Pengamatan yang dilakukan di antaranya:

\section{Morfologi Bunga}

Dilakukan pengamatan pada karakter posisi bunga, posisi stigma terhadap anther, panjang stamen, panjang tangkai putik, jumlah anther, warna anther, dan warna benang sari. Pengamatan menggunakan deskriptor Manual Gráfico para la Descripción Varietal de Tomate de Cáscara (Physalis ixocarpa Brot. ex Horm.) (Peña-Lomelí et al., 2011), Husk Tomato UPOV Code: PHYSA Guidelines for the Conduct of Tests for Distinctness, Uniformity dan Stability: Husk Tomato (Physalis philadelphica Lam., Physalis ixocarpa Brot., Physalis pruinosa L., dan Physalis P. angulata L.) (UPOV, 2005), dan A taxonomic analysis of the species of Physalis L. (Solanaceae) based on morphological characters (Beest et al., 1999) sebagai acuan untuk mengamati karakter tanaman.

2. Kompatibilitas persilangan (\%)

Terbentuknya buah setelah dilakukannya penyerbukan merupakan indikator terjadinya pembuahan, dan calon buah akan membesar. Persentase keberhasilan suatu persilangan yang menunjukkan kompatibilitas dihitung dengan rumus:

$\frac{\text { jumlah buah yang terbentuk }}{\text { jumlah bunga yang disilangkan }} \times 100 \%$ Dalam menentukan tingkat kompatibilitas digunakan klasifikasi Hawlader dan Mian (1997), yaitu suatu persilangan dinyatakan kompatibel, jika persentase keberhasilan $\geq 50 \%$, inkompatibilitas sebagian, jika persentase keberhasilan $10 \% \quad-\quad<50 \%$, dan inkompatibilitas penuh, jika persentase keberhasilan $<10 \%$. 
3. Beda rata-rata karakter buah dan biji

Pada hasil persilangan dilakukan pengamatan pada karakter bobot buah, panjang dan lebar buah, serta jumlah biji pada buah hasil penyerbukan sendiri dan penyerbukan silang hibridisasi interspesifik. Uji beda rata-rata dilakukan terhadap data karakter buah dan biji dari hasil penyerbukan sendiri dan penyerbukan silang interspesifik menggunakan uji $\mathrm{t}$ Student dua arah pada taraf $5 \%$. Pengolahan data hasil pengamatan penelitian kompatibilitas persilangan ini menggunakan software Microsoft Excel 2013. Berikut merupakan rumus uji $\mathrm{t}$ Student menurut (Kim, 2015).

$$
t=\frac{\overline{X_{1}}-\bar{X}_{2}}{\sqrt{\frac{s_{1}^{2}}{n_{1}}+\frac{s_{2}^{2}}{n_{2}}}}
$$

Keterangan :

$\mathrm{t}=\mathrm{t}$ hitung

$\bar{X}=$ rata-rata karakter

n1, n2 = jumlah sampel

$s^{2}=$ varians

\section{HASIL DAN PEMBAHASAN}

\section{MORFOLOGI BUNGA CIPLUKAN}

Ciplukan memiliki morfologi bunga lengkap. Anthesis pada bunga ciplukan terjadi sebelum anther bunga mengalami dehiscence yang terjadi pada jam 9-11 pagi. Pengamatan dilakukan dengan mengamati karakter morfologi bunga ciplukan (Tabel 1).

P. angulata (PAN-69281) memiliki posisi bunga tegak dengan posisi stigma di bawah anther. Panjang stamen $5 \mathrm{~mm}$ dengan 5 anther berwarna ungu. Benang sari berwarna kuning dan panjang benang sari $4 \mathrm{~mm}$ (Gambar 1). P. pruinosa (PPN+3101) memiliki bunga dengan posisi intermediate dengan posisi stigma sejajar dengan anther. Anther bunga berwarna kuning berjumlah 5 dengan panjang stamen $4 \mathrm{~mm}$. Memiliki kepala sari bunga berwarna ungu dengan panjang tangkai putik $4 \mathrm{~mm}$ (Gambar 2).

Table 1. Karakter morfologi bunga ciplukan (Physalis spp)

\begin{tabular}{|c|c|c|c|c|c|c|}
\hline No. & Karakter & $\begin{array}{l}\text { P. angulata } \\
\text { (PAN-69281) }\end{array}$ & $\begin{array}{l}\text { P. pruinosa } \\
\text { (PPN+3101) }\end{array}$ & $\begin{array}{c}\text { P. peruviana } \\
\text { (PPV-45311-03) }\end{array}$ & $\begin{array}{c}\text { P. pubescens } \\
\text { (PPB-68154-04) }\end{array}$ & $\begin{array}{c}\text { P. ixocarpa } \\
\text { (PIX-4418-2) }\end{array}$ \\
\hline 1 & Posisi bunga & Tegak & Intermediate & Intermediate & Intermediate & Intermediate \\
\hline 2 & $\begin{array}{l}\text { Panjang stamen } \\
(\mathrm{mm})\end{array}$ & 5 & 4 & 7 & 5 & 7 \\
\hline 3 & Jumlah anther & 5 & 5 & 5 & 5 & 5 \\
\hline 4 & Warna anther & Ungu & Kuning & Kuning & Kuning & Ungu \\
\hline 5 & $\begin{array}{l}\text { Panjang tangkai } \\
\text { putik }(\mathrm{mm})\end{array}$ & 4 & 4 & 6 & 4 & 8 \\
\hline 6 & Warna benang sari & Kuning & Ungu & Ungu & Hijau muda & Ungu \\
\hline 7 & $\begin{array}{l}\text { Posisi stigma } \\
\text { terhadap anther }\end{array}$ & Di bawah & Di antara & Di bawah & Di bawah & Di atas \\
\hline
\end{tabular}

P. peruviana (PPV-45311-03) memiliki posisi bunga intermediate dan posisi stigma di bawah anther. Bunga mempunyai 5 anther bunga berwarna kuning dengan panjang stamen $7 \mathrm{~mm}$. Benang sari bunga berwarna ungu dengan panjang tangkai putik $6 \mathrm{~mm}$ (Gambar 3). Morfologi bunga
P. pubescens (PPB-68154-04) memiliki posisi bunga intermediate dan posisi stigma di bawah anther. Terdapat 5 anther bunga berwarna kuning dengan panjang stamen $5 \mathrm{~mm}$. Benang sari berwarna hijau muda dan panjang tangkai putik $4 \mathrm{~mm}$ (Gambar 4). 

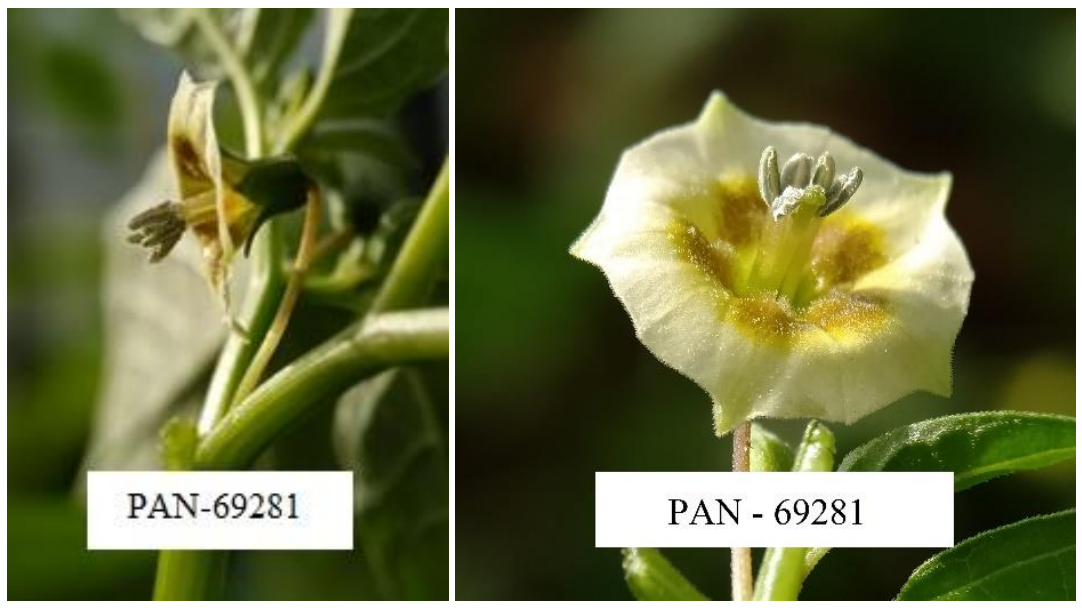

Gambar 1. Morfologi bunga P. angulata (PAN-69281)
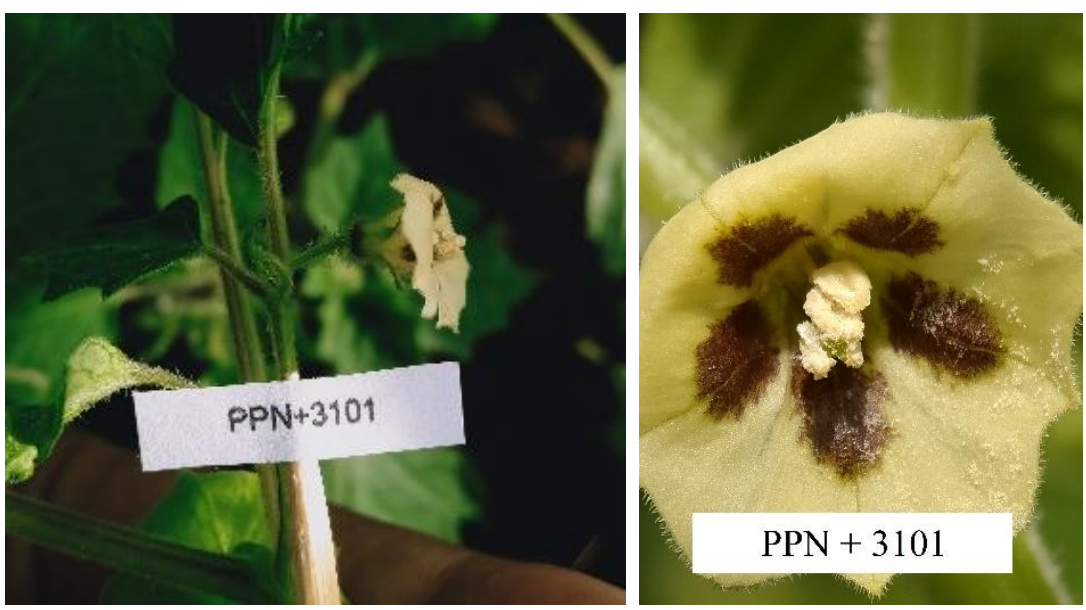

Gambar 2. Morfologi bunga P. pruinosa (PPN+3101).

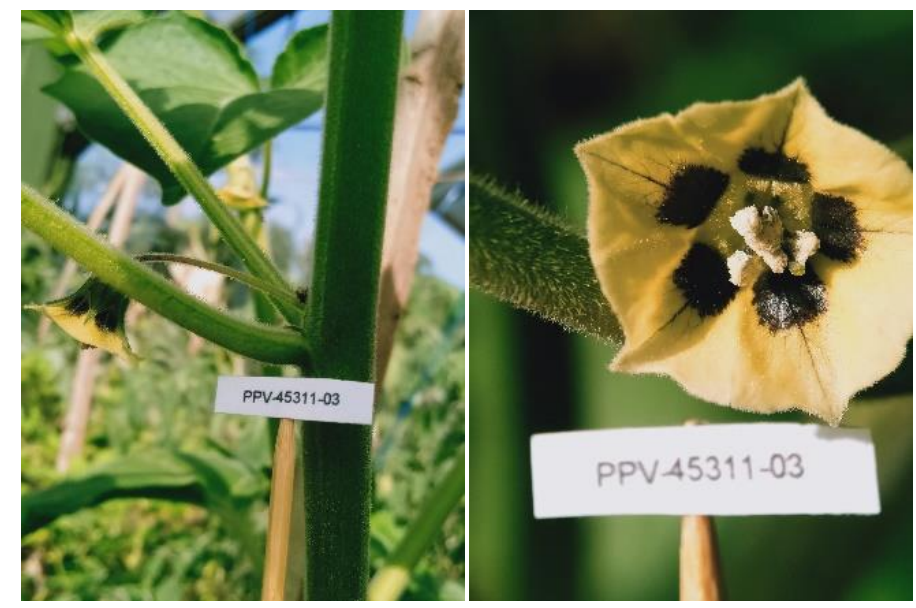

Gambar 3. Morfologi bunga P. peruviana (PPV-45311-03). 

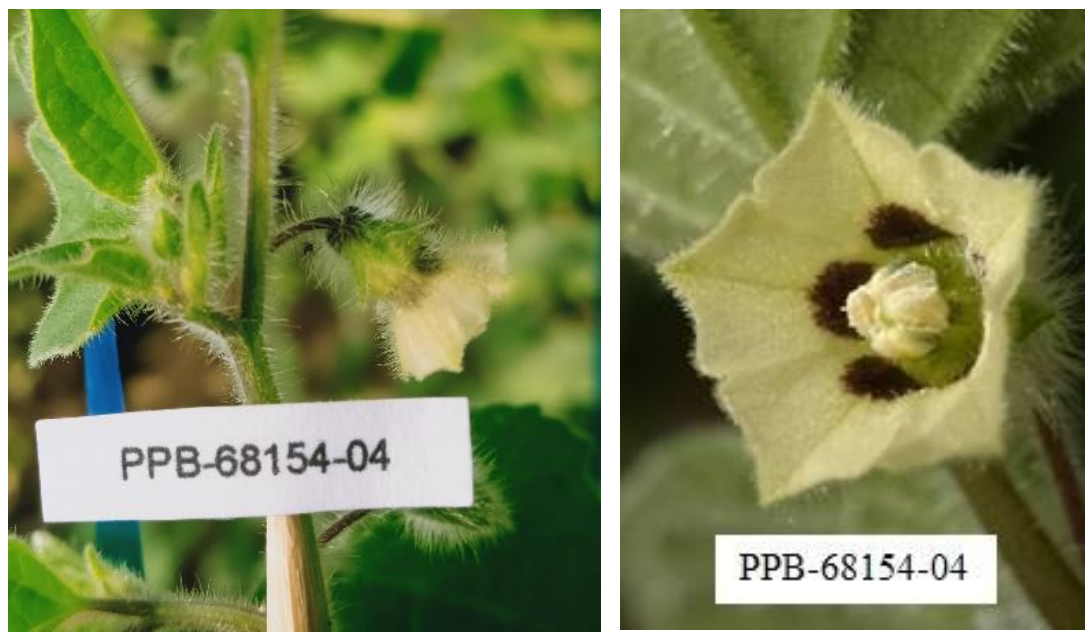

Gambar 4. Morfologi bunga P. pubescens (PPB-68154-04).
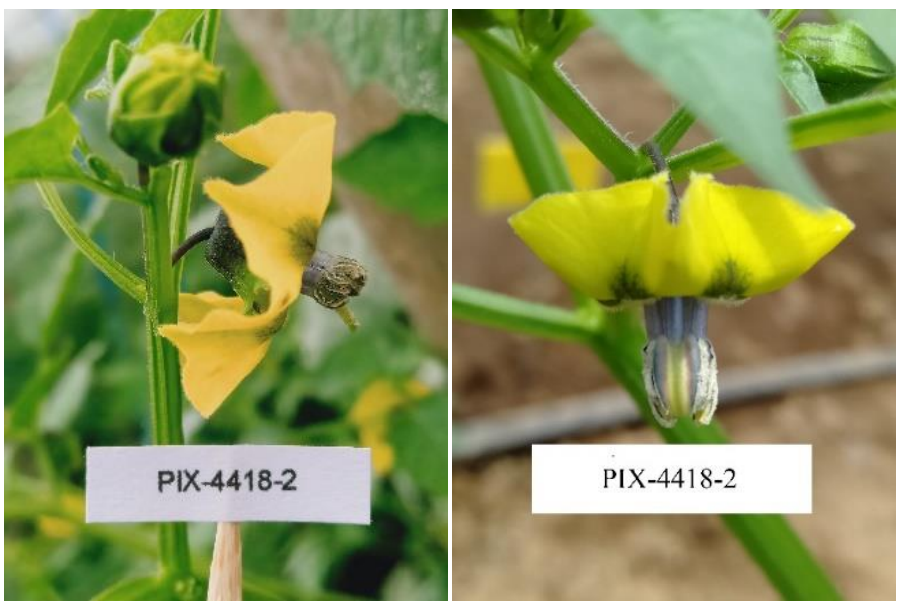

Gambar 5. Morfologi bunga P. ixocarpa (PIX-4418-2).

P. ixocarpa (PIX-4418-2) memiliki posisi bunga intermediate dan posisi stigma di atas anther. Bunga mempunyai 5 anther berwarna ungu dengan panjang stamen 7 $\mathrm{mm}$. Benang sari bunga berwarna ungu dengan panjang tangkai putik $8 \mathrm{~mm}$ (Gambar 5).

\section{KOMPATIBILITAS PERSILANGAN}

Kompatibilitas persilangan adalah kesesuaian organ betina dan jantan dalam melakukan penyerbukan dan diikuti dengan proses pembuahan (Frankel \& Galun, 1977) . Ketidakcocokan pada tingkat alel, gen, dan kromosom dalam berpasangan dapat menyebabkan kegagalan terjadinya pembuahan (inkompatibilitas) (Sahagún-castellanos, 1999). Keberhasilan suatu persilangan ditandai dengan berkembangnya bakal buah hingga terbentuknya biji. Inkompatibilitas pada persilangan terjadi diakibatkan oleh tidak cocoknya alel organ jantan dan betina yang terjadi sehingga sel jantan gagal membuahi sel betina (Lewis, 1949; Syukur et al., 2018). Persentase keberhasilan persilangan didapatkan dari jumlah buah terbentuk dibagi dengan persilangan yang dilakukan (Tabel 2). Berdasarkan hasil penelitian, dari 25 kombinasi persilangan yang dilakukan didapatkan 11 kombinasi persilangan yang berhasil membentuk buah dan biji. 
Tabel 2. Kompatibilitas persilangan Physalis

\begin{tabular}{|c|c|c|c|c|c|}
\hline No. & Kombinasi & $\begin{array}{c}\text { Jumlah } \\
\text { persilangan }\end{array}$ & $\begin{array}{c}\text { Jumlah } \\
\text { keberhasilan }\end{array}$ & $\begin{array}{c}\text { Persentase } \\
\text { keberhasilan }\end{array}$ & Keterangan \\
\hline \multirow[t]{2}{*}{1} & P. angulata (PAN-69281) $\mathrm{x}$ & 20 & 20 & 100 & Kompatibel \\
\hline & P. angulata (PAN-69281) & & & & \\
\hline \multirow[t]{2}{*}{2} & P. angulata (PAN-69281) $\mathrm{x}$ & - & - & - & - \\
\hline & P. peruviana (PPV-45311-03) & & & & \\
\hline \multirow[t]{2}{*}{3} & P. angulata (PAN-69281) $\times$ & 26 & 2 & 7.69 & Inkompatibel \\
\hline & P. pubescens (PPB-68154-04) & & & & \\
\hline \multirow[t]{2}{*}{4} & P. angulata (PAN-69281) $x$ & 40 & 0 & 0 & Inkompatibel \\
\hline & P. pruinosa (PPN+3101) & & & & \\
\hline \multirow[t]{2}{*}{5} & P. angulata (PAN-69281) $\mathrm{x}$ & 38 & 11 & 28.94 & Inkompatibel \\
\hline & P. ixocarpa (PIX-4418-2) & & & & sebagian \\
\hline \multirow[t]{2}{*}{6} & P. peruviana (PPV-45311-03) $\mathrm{x}$ & 20 & 20 & 100 & Kompatibel \\
\hline & P. peruviana (PPV-45311-03) & & & & \\
\hline \multirow[t]{2}{*}{7} & P. peruviana (PPV-45311-03) $\mathrm{x}$ & 17 & 0 & 0 & Inkompatibel \\
\hline & P. angulata (PAN-69281) & & & & \\
\hline \multirow[t]{2}{*}{8} & P. peruviana (PPV-45311-03) $\mathrm{x}$ & 9 & 0 & 0 & Inkompatibel \\
\hline & P. pubescens (PPB-68154-04) & & & & \\
\hline \multirow[t]{2}{*}{9} & P. peruviana (PPV-45311-03) $\mathrm{x}$ & 11 & 0 & 0 & Inkompatibel \\
\hline & P. pruinosa (PPN+3101) & & & & \\
\hline \multirow[t]{2}{*}{10} & P. peruviana (PPV-45311-03) $\mathrm{x}$ & 24 & 0 & 0 & Inkompatibel \\
\hline & P. ixocarpa (PIX-4418-2) & & & & \\
\hline \multirow[t]{2}{*}{11} & P. pubescens (PPB-68154-04) x & 20 & 20 & 100 & Kompatibel \\
\hline & P. pubescens (PPB-68154-04) & & & & \\
\hline \multirow[t]{2}{*}{12} & P. pubescens (PPB-68154-04) x & 39 & 20 & 51.28 & Kompatibel \\
\hline & P. angulata (PAN-69281) & & & & \\
\hline \multirow[t]{2}{*}{13} & P. pubescens (PPB-68154-04) x & - & - & - & - \\
\hline & P. peruviana (PPV-45311-03) & & & & \\
\hline \multirow[t]{2}{*}{14} & P. pubescens (PPB-68154-04) x & 26 & 0 & 0 & Inkompatibel \\
\hline & P. pruinosa (PPN+3101) & & & & \\
\hline \multirow[t]{2}{*}{15} & P. pubescens (PPB-68154-04) x & 31 & 11 & 35.48 & Inkompatibel \\
\hline & P. ixocarpa (PIX-4418-2) & & & & sebagian \\
\hline \multirow[t]{2}{*}{16} & P. pruinosa $(\mathrm{PPN}+3101) \mathrm{x}$ & 20 & 20 & 100 & Kompatibel \\
\hline & P. pruinosa (PPN+3101) & & & & \\
\hline \multirow[t]{2}{*}{17} & P. pruinosa $(\mathrm{PPN}+3101) \mathrm{x}$ & 21 & 3 & 14.28 & Inkompatibel \\
\hline & P. angulata (PAN-69281) & & & & sebagian \\
\hline \multirow[t]{2}{*}{18} & P. pruinosa $(\mathrm{PPN}+3101) \times$ & - & - & - & - \\
\hline & P. peruviana (PPV-45311-03) & & & & \\
\hline \multirow[t]{2}{*}{19} & P. pruinosa $(\mathrm{PPN}+3101) \mathrm{x}$ & 28 & 0 & 0 & Inkompatibel \\
\hline & P. pubescens (PPB-68154-04) & & & & \\
\hline \multirow[t]{2}{*}{20} & P. pruinosa $(\mathrm{PPN}+3101) \mathrm{x}$ & 17 & 2 & 11.76 & Inkompatibel \\
\hline & P. ixocarpa (PIX-4418-2) & & & & sebagian \\
\hline \multirow[t]{2}{*}{21} & P. ixocarpa (PIX-4418-2) x & 20 & 20 & 100 & Kompatibel \\
\hline & P. ixocarpa (PIX-4418-2) & & & & \\
\hline 22 & P. ixocarpa (PIX-4418-2) x & 22 & 0 & 0 & Inkompatibel \\
\hline & P. angulata (PAN-69281) & & & & \\
\hline 23 & P. ixocarpa (PIX-4418-2) x & - & - & - & - \\
\hline & P. peruviana (PPV-45311-03) & & & & \\
\hline 24 & P. ixocarpa (PIX-4418-2) x & 16 & 0 & 0 & Inkompatibel \\
\hline & P. pubescens (PPB-68154-04) & & & & \\
\hline 25 & P. ixocarpa (PIX-4418-2) x & 12 & 0 & 0 & Inkompatibel \\
\hline & P. pruinosa (PPN+3101) & & & & \\
\hline
\end{tabular}

Keterangan: -) Tidak dilakukan persilangan. 
Penyerbukan sendiri pada setiap spesies menunjukkan keberhasilan persilangan sebesar $100 \%$. Hal ini menunjukkan semua spesies yang digunakan pada penelitian ini menunjukkan kompatibilitas sendiri (selfcompatibility). Pada kombinasi persilangan interspesifik diperoleh tingkat kompatibilitas yang bervariasi. Pada persilangan interspesifik $P$. pubescens (PPB-68154-04) ketika menjadi tetua betina terhadap $P$. angulata (PAN-69281) termasuk tingkat kompatibel dengan persentase sebesar $51.28 \%$. Persilangan $P$. pubescens (PPB-68154-04) dengan $P$. ixocarpa (PIX-4418-2) dengan persentase sebesar $35.48 \%$ termasuk ke dalam tingkat inkompatibilitas sebagian.

Tingkat inkompatibilitas sebagian (partial self-incompatibility) terjadi pada persilangan interspesifik $P$. pruinosa (PPN+3101) sebagai tetua betina terhadap $P$. angulata (PAN-69281) dan P. ixocarpa (PIX-4418-2) sebagai jantan yang memiliki persentase keberhasilan persilangan masing - masing sebesar $14.28 \%$ dan $11.76 \%$. Tidak didapatkan keberhasilan pada persilangan interspesifik antara $P$. pubescens (PPB-68154-04) dengan $P$. pruinosa (PPN+3101) begitu pula pada persilangan sebaliknya.

Tingkat inkompatibilitas sebagian terdapat pada persilangan $P$. angulata (PAN-69281) X P. ixocarpa (PIX-4418-2) dengan persentase sebesar 28.94\%, sedangkan pada persilangan $P$. angulata (PAN-69281) dengan P. pubescens (PPB68154-04) termasuk inkompatibilitas penuh dengan persentase sebesar $7.69 \%$. Tidak didapatkan keberhasilan persilangan interspesifik antara $P$. angulata (PAN69281) sebagai tetua betina dari $P$. pruinosa (PPN+3101), hal ini berbeda dengan resiproknya.
Persilangan interspesifik dengan tingkat inkompatibilitas penuh dengan persentase sebesar $0 \%$ terdapat pada persilangan $P$. angulata (PAN-69281) $\times \quad P$. pruinosa (PPN+3101), P. pruinosa (PPN+3101) x $P$. pubescens (PPB-68154-04), P. pruinosa (PPN+3101) x P. ixocarpa (PIX-4418-2), dan persilangan interspesifik pada $P$. ixocarpa (PIX-4418-2) dan P. peruviana (PPV-4531103) ketika menjadi tetua betina dari semua spesies yang diuji.

Ganapathi et al. (1991) menuliskan bahwa terjadi kegagalan dalam persilangan antara $P$. pubescens dengan $P$. peruviana dan resiproknya. Ketidakberhasilan persilangan juga terjadi pada hibridisasi interspesifik antara $P$. angulata dengan $P$. peruviana yang dilakukan oleh Azeez dan Faluyi (2018). Menzel (1951) mencatat kegagalan persilangan ketika $P$. ixocarpa menjadi tetua betina dari persilangan dengan $P$. pubescens, $P$. peruviana, $P$. angulata, dan $P$. pruinosa.

Pada hibridisasi interspesifik inkompatibilitas dapat berupa kegagalan pembuahan yang ditandai dengan rontoknya bunga dan berhasilnya pembuahan hingga terbentuk bakal buah namun beberapa hari kemudian buah gugur. Hambatan keberhasilan persilangan dapat muncul sebelum fertilisasi (prezygotic barriers) dan setelah fertilisasi (post-zygotic barriers) (Barone et al., 1992; Martins et al., 2015). Hambatan pre-zygotic dapat berupa kegagalan perkecambahan serbuk sari dan terhambatnya perkembangan tabung serbuk sari (Barone et al., 1992; Hajjar \& Hodgkin, 2007). Hambatan post-zygotic barriers yang paling sering terjadi berupa berhasilnya pembentukan buah namun mengandung biji yang abnormal, dan memiliki ukuran yang berbeda dari tetuanya serta berwarna 
gelap yang mengindikasi degenerasi biji (Martins et al., 2015).

Tabel 3. Data hasil pengamatan kuantitatif buah

\begin{tabular}{|c|c|c|c|c|c|}
\hline No. & Kombinasi & $\begin{array}{l}\text { Rata-rata } \\
\text { bobot buah }\end{array}$ & $\begin{array}{c}\text { Rata-rata } \\
\text { panjang buah }\end{array}$ & $\begin{array}{l}\text { Rata-rata } \\
\text { lebar buah }\end{array}$ & $\begin{array}{r}\text { Rata-rata } \\
\text { jumlah biji }\end{array}$ \\
\hline \multirow[t]{2}{*}{1} & P. angulata (PAN-69281) $\mathrm{x}$ & 1.50 & 13.57 & 12.66 & 177.00 \\
\hline & P. angulata (PAN-69281) & & & & \\
\hline \multirow[t]{2}{*}{2} & P. angulata (PAN-69281) $\mathrm{x}$ & 0.21 & 7.20 & 6.10 & 3.50 \\
\hline & P. pubescens (PPB-68154-04) & & & & \\
\hline \multirow[t]{2}{*}{3} & P. angulata (PAN-69281) $\mathrm{x}$ & 0.89 & 11.45 & 10.45 & 104.23 \\
\hline & P. ixocarpa (PIX-4418-2) & & & & \\
\hline \multirow[t]{2}{*}{4} & P. peruviana (PPV-45311-03) $\mathrm{x}$ & 1.53 & 12.57 & 12.05 & 134.25 \\
\hline & P. peruviana (PPV-45311-03) & & & & \\
\hline \multirow[t]{2}{*}{5} & P. pubescens (PPB-68154-04) x & 1.23 & 12.07 & 12.80 & 148.75 \\
\hline & P. pubescens (PPB-68154-04) & & & & \\
\hline \multirow[t]{2}{*}{6} & P. pubescens (PPB-68154-04) x & 0.97 & 11.12 & 11.13 & 117.50 \\
\hline & P. angulata (PAN-69281) & & & & \\
\hline \multirow[t]{2}{*}{7} & P. pubescens (PPB-68154-04)x & 0.23 & 7.00 & 6.66 & 1.82 \\
\hline & P. ixocarpa (PIX-4418-2) & & & & \\
\hline \multirow[t]{2}{*}{8} & P. pruinosa $(\mathrm{PPN}+3101) \mathrm{x}$ & 1.16 & 11.75 & 11.90 & 149.40 \\
\hline & P. pruinosa (PPN+3101) & & & & \\
\hline \multirow[t]{2}{*}{9} & P. pruinosa (PPN+3101) $\mathrm{x}$ & 0.26 & 6.60 & 6.53 & 3.00 \\
\hline & P. angulata (PAN-69281) & & & & \\
\hline \multirow[t]{2}{*}{10} & P. pruinosa (PPN+3101) $\mathrm{x}$ & 0.37 & 7.20 & 8.45 & 2.50 \\
\hline & P. ixocarpa (PIX-4418-2) & & & & \\
\hline \multirow[t]{2}{*}{11} & P. ixocarpa (PIX-4418-2) x & 2.46 & 15.79 & 15.43 & 21.25 \\
\hline & P. ixocarpa (PIX-4418-2) & & & & \\
\hline
\end{tabular}

Pada penelitian ini, kegagalan pembuahan ditandai dengan bunga mengering dan tidak berkembang dan pada $5-8$ hari setelah penyerbukan bunga mengalami rontok. Peristiwa bunga rontok terjadi pada persilangan $P$. angulata (PAN69281) $\times$ P. pruinosa (PPN+3101) dan resiproknya, $P$. pruinosa $(\mathrm{PPN}+3101) \times P$. pubescens (PPB-68154-04), serta pada persilangan $P$. peruviana (PPV-45311-03) sebagai tetua betina dari semua spesies yang diuji. Fenomena inkompatibilitas yang kedua yaitu pembuahan berhasil hingga terbentuk bakal buah namun pada $17-23$ hari setelah penyerbukan buah gugur. Fenomena tidak berkembangnya bakal buah dengan normal hingga rontok terjadi pada persilangan $P$. angulata (PAN-69281) $x$ P. pruinosa $(\mathrm{PPN}+3101)$, $P$. angulata (PAN-69281) X P. ixocarpa (PIX-4418-2), $P$. pubescens (PPB-68154-04) × $P$. pruinosa
(PPN+3101) dan P. pruinosa $(\mathrm{PPN}+3101) \mathrm{x}$ P. ixocarpa (PIX-4418-2). Azeez \& Faluyi (2018), melakukan persilangan terhadap tanaman Physalis dan menemukan fenomena terjadinya aborsi pada ovarium yang telah dibuahi pada beberapa minggu setelah pembuahan. Pada persilangan interspesifik sering terjadi tidak berkembangnya bunga setelah dilakukan penyerbukan hingga bunga mengering dan rontok serta terjadinya keberhasilan pembuahan yang diikuti dengan aborsi embrio (Menzel, 1951). Aborsi embrio terjadi karena embrio dan endosperm mengalami degenerasi, endosperm berkembang lebih lambat, sehingga perkembangan embrio tertunda dan kemudian gugur (Barone et al., 1992; Geerts et al., 2002; Pickersgill, 1971).

Pada buah yang terbentuk pada hasil penyerbukan sendiri dan penyerbukan 
silang hibridisasi interspesifik dilakukan pengamatan karakteristik buah dan biji (Tabel 3), meliputi rata-rata bobot buah, panjang dan lebar buah, serta jumlah biji.

\section{VARIASI PENAMPILAN KARAKTER BUAH DAN BIJI}

Data hasil persilangan dianalisis untuk melihat apakah terdapat perbedaan ratarata antara buah hasil penyerbukan sendiri dan hasil penyerbukan silang melalui hibridisasi interspesifik pada tiap karakternya menggunakan uji t-Student. Analisis uji t-Student dilakukan antara kombinasi hasil persilangan selfing $P$. angulata dengan hasil interspesifik $P$. angulata (PAN-69281) X P. ixocarpa (PIX4418-2) dan $P$. angulata (PAN-69281) $\times P$. pubescens (PPB-68154-04), hasil persilangan selfing $P$. pubescens dengan hasil interspesifik $P$. pubescens (PPB68154-04) X P. ixocarpa (PIX-4418-2) dan $P$. pubescens (PPB-68154-04) × $P$. angulata (PAN-6928), serta pada hasil persilangan selfing $P$. pruinosa dengan hasil persilangan interspesifik $P$. pruinosa $(\mathrm{PPN}+3101) \times P$. ixocarpa (PIX-4418-2) dan $P$. pruinosa (PPN+3101) X P. angulata (PAN-69281).

Berdasarkan hasil analisis yang dilakukan, tidak terdapat perbedaan yang nyata pada karakter bobot, panjang, serta lebar buah pada hasil persilangan interspesifik $P$. angulata (PAN-69281) x $P$. pubescens (PPB-68154-04) terhadap selfingnya. Sedangkan terdapat perbedaan yang nyata pada karakter jumlah biji pada hasil persilangan $P$. angulata (PAN-69281) $x$ P. pubescens (PPB-68154-04) dan semua karakter pada hasil persilangan $P$. angulata (PAN-69281) X P. ixocarpa (PIX-4418-2) terhadap selfingnya. Hal ini menunjukkan persilangan interspesifik antara $P$. angulata
(PAN-69281) x P. ixocarpa (PIX-4418-2) memberikan pengaruh yang nyata terhadap karakter hasil buah dan biji. Sedangkan pada persilangan $P$. angulata (PAN-69281) x P. pubescens (PPB-6815404) pengaruh persilangan interspesifik terjadi pada karakter jumlah biji (Tabel 4).

Hasil persilangan $P$. pubescens (PPB68154-04) X P. ixocarpa (PIX-4418-2) memiliki perbedaan yang nyata pada semua karakter terhadap selfingnya. Pada hasil persilangan $P$. pubescens (PPB-6815404) $\times$ P. angulata (PAN-6928) memiliki perbedaan yang nyata pada karakter bobot buah, panjang buah dan jumlah biji serta pada karakter lebar buah menunjukkan hasil tidak berbeda nyata terhadap selfingnya. Hasil penelitian menunjukkan persilangan interspesifik pada $P$. pubescens (PPB-68154-04) x P. angulata (PAN-6928) tidak memberikan pengaruh yang nyata terhadap karakter lebar buah. sedangkan pada persilangan interspesifik $P$. pubescens (PPB-68154-04) x P. ixocarpa (PIX-4418-2) memberikan pengaruh yang nyata terhadap karakter hasil buah dan biji (Tabel 5).

Pada persilangan $P$. pruinosa (PPN+3101) x P. ixocarpa (PIX-4418-2) dan $P$. pruinosa $(\mathrm{PPN}+3101) \times P$. angulata $(\mathrm{PAN}-$ 69281) terdapat perbedaan yang nyata pada semua karakter terhadap selfingnya. Persilangan interspesifik pada $P$. pruinosa (PPN+3101) dengan P. ixocarpa (PIX-44182) dan $P$. angulata (PAN-69281) memberikan pengaruh terhadap hasil buah dan biji. Berdasarkan analisis, pada hasil persilangan interspesifik $P$. pruinosa (PPN+3101), P. angulata (PAN-69281), dan $P$. pubescens (PPB-68154-04) memiliki perbedaan yang nyata pada karakter jumlah biji. 
Tabel 4. Perbandingan rata-rata karakter kuantitatif persilangan $P$. angulata (PAN-69281)

\begin{tabular}{llcccccc}
\hline & \multicolumn{1}{c}{ Karakter } & $\begin{array}{c}\text { P. angulata } \\
\text { (PAN-69281) }\end{array}$ & $\begin{array}{c}\text { P. pubescens } \\
\text { (PPB-68154-04) }\end{array}$ & \multicolumn{2}{c}{$\begin{array}{c}\text { P. ixocarpa } \\
\text { (PIX-4418-2) }\end{array}$} \\
\cline { 3 - 8 } & & Rata-rata & P & Rata-rata & P & Rata-rata & P \\
\hline P. angulata & Bobot buah (g) & 1.50 & - & 0.21 & 0.08 & 0.89 & $0.00^{* *}$ \\
(PAN-69281) & Panjang buah (mm) & 13.57 & - & 7.20 & 0.22 & 11.45 & $0.00^{* *}$ \\
& Lebar buah (mm) & 12.66 & - & 6.10 & 0.15 & 10.45 & $0.00^{* *}$ \\
& Jumlah biji & 177.00 & - & 3.50 & $0.00^{* *}$ & 104.23 & $0.00^{* *}$ \\
\hline
\end{tabular}

Keterangan: ${ }^{* *}=$ nilai $\mathrm{P} \leq 0.01,{ }^{*}=$ nilai $\mathrm{P} \leq 0.05$, berbeda nyata berdasarkan hasil uji-t student

Tabel 5. Perbandingan rata-rata karakter kuantitatif persilangan $P$. pubescens (PPB-68154-04)

\begin{tabular}{|c|c|c|c|c|c|c|c|}
\hline के & \multirow[t]{2}{*}{ Karakter } & \multicolumn{2}{|l|}{$\begin{array}{c}\text { P. pubescens } \\
\text { (PPB-68154-04) }\end{array}$} & \multicolumn{2}{|l|}{$\begin{array}{l}\text { P. angulata } \\
\text { (PAN-6928) }\end{array}$} & \multicolumn{2}{|c|}{$\begin{array}{l}\text { P. ixocarpa } \\
\text { (PIX-4418-2) }\end{array}$} \\
\hline 8 & & Rata-rata & $\mathrm{P}$ & Rata-rata & $P$ & Rata-rata & $\mathrm{P}$ \\
\hline P. pubescens & Bobot buah (g) & 1.23 & - & 0.97 & $0.01^{*}$ & 0.23 & $0.00 * *$ \\
\hline (PPB-68154-04) & Panjang buah (mm) & 12.07 & - & 11.12 & $0.00 * *$ & 7.00 & $0.00 * *$ \\
\hline & Lebar buah (mm) & 12.80 & - & 11.13 & 0.06 & 6.66 & $0.00 * *$ \\
\hline & Jumlah biji & 148.75 & - & 117.50 & $0.02 *$ & 1.82 & $0.00 * *$ \\
\hline
\end{tabular}

Keterangan: ${ }^{* *}=$ nilai $\mathrm{P} \leq 0.01,{ }^{*}=$ nilai $\mathrm{P} \leq 0.05$, berbeda nyata berdasarkan hasil uji-t student.

Tabel 6. Perbandingan rata-rata karakter kuantitatif persilangan P. pruinosa $(\mathrm{PPN}+3101)$

\begin{tabular}{llcccccc}
\hline & \multicolumn{1}{c}{ Karakter } & $\begin{array}{c}\text { P. pruinosa } \\
\text { (PPN+3101) }\end{array}$ & $\begin{array}{c}\text { P. angulata } \\
\text { (PAN-69281) }\end{array}$ & \multicolumn{2}{c}{$\begin{array}{c}\text { P. ixocarpa } \\
\text { (PIX-4418-2) }\end{array}$} \\
\cline { 3 - 7 } & & Rata-rata & P & Rata-rata & P & Rata-rata & P \\
\hline P. pruinosa & Bobot buah (g) & 1.16 & - & 0.26 & $0.00^{* *}$ & 0.37 & $0.00^{* *}$ \\
(PPN+3101) & Panjang buah (mm) & 11.75 & - & 6.60 & $0.00^{* *}$ & 7.20 & $0.01^{* *}$ \\
& Lebar buah $(\mathrm{mm})$ & 11.90 & - & 6.53 & $0.00^{* *}$ & 8.45 & $0.00^{* *}$ \\
& Jumlah biji & 149.40 & - & 3.00 & $0.00^{* *}$ & 2.50 & $0.00^{* *}$ \\
\hline
\end{tabular}

Keterangan: ${ }^{* *}=$ nilai $\mathrm{P} \leq 0.01,{ }^{*}=$ nilai $\mathrm{P} \leq 0.05$, berbeda nyata berdasarkan hasil uji-t student.

Berdasarkan hasil penelitian, didapatkan adanya perbedaan pada karakter kuantitatif buah dan biji antara buah hasil penyerbukan sendiri dengan hasil penyerbukan silang hibridisasi interspesifik (Tabel 3 - Tabel 6). Hal ini terjadi karena pengaruh serbuksari dari tetua jantan yang menyebabkan perubahan pada penampilan buah dan biji yang dihasilkan oleh tetua betina. Hal ini dapat terjadi dengan adanya kemungkinan pengaruh dari xenia ataupun metaxenia. Xenia dan metaxenia sangat bergantung pada genotipe tetua jantan sebagai pendonor polen dan genotipe tetua betina sebagai tempat berkembangnya buah hasil persilangan. Xenia dan metaxenia ialah transmisi sifat dari polinator terhadap jaringan tetua betina, dan ini sudah dipelajari pada persilangan interspesifik tomat yang masih satu famili dengan ciplukan, yaitu Solanaceae bahwa terdapat perubahan morfologi daging buah dan biji pada hasil penyerbukan di tetua betina (Piotto et al., 2013).

Determinasi pasangan persilangan yang kompatibel akan membuka pengetahuan baru bagi pengembangan program pemuliaan tanaman melalui rekombinasi genetik secara seksual, dan pasangan persilangan yang tidak kompatibel akan memberikan peluang rekombinasi melalui penerapan teknologi khususnya mengintroduksi karakter sifat unggul yang diinginkan (Douglas \& Freyre, 2016). Berdasarkan hasil persilangan interspesifik 
pada ciplukan ini dapat diketahui pasangan spesies yang mampu bersilang dan menghasilkan buah dan pasangan spesies yang menunjukkan ketidakmampuan menghasilkan buah. Dari penelitian ini juga dapat diketahui bahwa terjadi xenia pada karakteristik kuantitatif buah dan biji hasil penyerbukan silang hibridisasi interspesifik. Informasi ini dapat dijadikan sebagai dasar untuk pemilihan tetua dan penerapan teknologi untuk perluasan keragaman genetik dan seleksi di dalam program pemuliaan tanaman ciplukan.

\section{SIMPULAN}

Berdasarkan penelitian morfologi bunga ciplukan termasuk bunga lengkap dan memiliki karakteristik yang berbeda setiap spesiesnya. Hasil persilangan interspesifik pada ciplukan memiliki tingkat kompatibilitas yang bervariasi. Penyerbukan sendiri pada setiap spesies mempunyai tingkat keberhasilan dan kompatibilitas $100 \%$. Penyerbukan silang hibridisasi interspesifik kompatibel terdapat pada persilangan $P$. angulata (PAN-69281) X P. ixocarpa (PIX-4418-2), $P$. pubescens (PPB-68154-04) × $P$. angulata (PAN-69281), P. pubescens (PPB-68154-04) $\mathrm{X}$ P. ixocarpa (PIX-4418-2), serta pada persilangan $P$. pruinosa (PPN+3101) dengan $P$. angulata (PAN-69281) dan $P$. ixocarpa (PIX-4418-2). Terdapat perbedaan pada karakter kuantitatif buah dan biji antara buah hasil penyerbukan sendiri dengan buah hasil penyerbukan silang hibridisasi interspesifik.

\section{DAFTAR PUSTAKA}

Abubakar, M. S., Musa, A. M., Ahmed, A., \& Hussaini, I. M. (2007). The perception and practice of traditional medicine in the treatment of cancers and inflammations by the Hausa and
Fulani tribes of Northern Nigeria. Journal of Ethnopharmacology, 111(3), 625-629. https://doi.org/10.1016/j.jep.2007.01 .011

Azeez, S. O., \& Faluyi, J. O. (2018). Hybridization in four Nigerian Physalis (Linn .) species. Notulae Scientia Biologicae, 10(2), 205-210. https://doi.org/10.25835/nsb102102 41

Barone, A., Del Giudice, A., \& Ng, N. Q. (1992). Barriers to interspecific hybridization between Vigna unguiculata and Vigna vexillata. Sexual Plant Reproduction, 5(3), 195200.

https://doi.org/10.1007/BF00189811

Beest, M. te, Berg, R. van den, \& Brandenburg, W. (1999). A taxonomic analysis of the species of Physalis L. (Solanaceae) based on morphological characters. In $M$. Sivadasan \& P. Mathew (Eds.), Mentor Book. Biodiversity, taxonomy and conservation of flowering plants, Calicut, Kerala, India, 1998 (pp. 8597).

Chautá-Mellizo, A., Campbell, S. A., Bonilla, M. A., Thaler, J. S., \& Poveda, K. (2012). Effects of natural and artificial pollination on fruit and offspring quality. Basic and Applied Ecology, 13(6), 524-532. https://doi.org/10.1016/j.baae.2012. 08.013

Djakbé, J. D., Ngakou, A., Christian, W., Faïbawe, E., \& Tchuenguem, N.-F. F. (2017). Pollination and yield components of Physalis minima (Solanaceae) as affected by the foraging activity of Apis mellifera (Hymenoptera: Apidae) and compost at Dang (Ngaoundéré, Cameroon). International Journal of Agronomy and Agricultural Research, 11(3), 4360. http://www.innspub.net/wpcontent/uploads/2017/10/IJAAR-

V11No3-p43-60.pdf

Douglas, A. C., \& Freyre, R. (2016). Sexual 
compatibility between eight Nolana L.f. (Solanaceae) species from Peru and Chile. Euphytica, 208(1), 33-46. https://doi.org/10.1007/s10681-0151483-3

Effendy, Respatijarti, \& Waluyo, B. (2018). Keragaman genetik dan heritabilitas karakter komponen hasil dan hasil ciplukan (Physalis sp.). Jurnal Agro, 5(1), 30-38. https://doi.org/10.15575/1864

Figueiredo, M. C. C., Passos, A. R., Hughes, F. M., Santos, K. S. dos, Silva, A. L. da, \& Soares, T. L. (2020). Reproductive biology of Physalis angulata L. (Solanaceae). Scientia Horticulturae, 267, 109307. https://doi.org/10.1016/j.scienta.202 0.109307

Frankel, R., \& Galun, E. (1977). Pollination Mechanisms, Reproduction and Plant Breeding. Springer-Verlag Berlin Heidelberg.

Ganapathi, A., Sudhakaran, S., \& Kulothungan, S. (1991). The diploid taxon in Indian natural populations of Physalis L. and its taxonomic significance. Cytologia., 56(2), 283288.

https://doi.org/10.1508/cytologia.56. 283

Geerts, P., Toussaint, A., Mergeai, G., \& Baudoin, J. P. (2002). Study of the early abortion in reciprocal crosses between Phaseolus vulgaris L. and Phaseolus polyanthus Greenm. Biotechnology, Agronomy and Society and Environment, 6(2), 109-119.

Hajjar, R., \& Hodgkin, T. (2007). The use of wild relatives in crop improvement: $A$ survey of developments over the last 20 years. Euphytica, 156(1-2), 1-13. https://doi.org/10.1007/s10681-0079363-0

Hawlader, M. S. H., \& Mian, M. A. K. (1997). Self-incompatibility studies in local cultivars of radish (Raphanus sativus L.) grown in Bangladesh. Euphytica, 96(3), 311-315. https://doi.org/10.1023/A:100309400
5226

He, Q.-P., Ma, L., Luo, J.-Y., He, F.-Y., Lou, L.-G., \& Hu, L.-H. (2007). Cytotoxic withanolides from Physalis angulata L. Chemistry and Biodiversity, 4(3), 443-449.

https://doi.org/10.1002/cbdv.200790 036

Jansky, S. H., \& Rouse, D. I. (2003). Multiple disease resistance in interspecific hybrids of potato. Plant Disease, 87, 266-272.

Jovel, E. M., Cabanillas, J., \& Towers, G. H. N. (1996). An ethnobotanical study of the traditional medicine of the Mestizo people of Suni Mirano, Loreto, Peru. Journal of Ethnopharmacology, 53(3), 149-156. https://doi.org/10.1016/03788741(96)01437-7

Kim, T. K. (2015). T test as a parametric statistic. Korean Journal of Anesthesiology, 68(6), 540. https://doi.org/10.4097/kjae.2015.68 .6 .540

Lagos B., T. C., Vallejo Cabrera, F. A., Criollo Escobar, H., \& Muñoz Flórez, J. E. (2008). Biología reproductiva de la uchuva [sexual reproduction of the cape gooseberry]. Acta Agronómica, 57(2), 81-87.

Lewis, D. (1949). Incompatibility in flowering plants. Biological Reviews, 24(4), 472-496. https://doi.org/10.1111/j.1469185X.1949.tb00584.x

Martins, K. C., Pereira, T. N. S., Souza, S. A. M., Rodrigues, R., \& do Amaral Junior, A. T. (2015). Crossability and evaluation of incompatibility barriers in crosses between Capsicum species. Crop Breeding and Applied Biotechnology, 15(3), 139-145. https://doi.org/10.1590/198470332015v15n3a25

Menzel, M. Y. (1951). The cytotaxonomy and genetics of Physalis. Proc Am Phylos Soc., 95(2), 132-183.

Mirzaee, F., Saeed Hosseini, A., Askian, R., \& Azadbakht, M. (2019). Therapeutic 
activities and phytochemistry of Physalis species based on traditional and modern medicine. Research Journal of Pharmacognosy, 6(4), 7996.

https://doi.org/10.22127/rjp.2019.93 529

Muniz, J., Kretzschmar, A. A., Rufato, L., Pelizza, T. R., Rufato, A. D. R., \& Macedo, T. A. de. (2014). General aspects of Physalis cultivation. Ciência Rural, 44(6), 964-970. https://doi.org/10.1590/\$010384782014005000006

Olorode, O., Olayanju, S., \& Garba, A. (2013). Physalis (Solanaceae) in Nigeria. Ife Journal of Science, 15(1), 101-109.

Peña-Lomelí, A., Magaña-Lira, N., GámezTorres, A., Mendoza-Celino, F., \& Pérez-Grajales, M. (2018). Manual pollination in two tomatillo (Physalis ixocarpa Brot. ex Horm.) varieties under greenhouse conditions. Revista Chapingo Serie Horticultura, 24(1), 13-26.

https://doi.org/10.5154/r.rchsh.2017. 02.011

Peña-Lomelí, A., Magaña-Lira, N., MontesHernández, S., Sánchez-Martínez, J., Santiaguillo-Hernández, J., Grimaldo Juárez, O., \& Con- treras-Rodríguez, A. (2011). Manual Gráfico para la Descripción Varietal de Tomate de Cáscara (Physalis ixocarpa Brot. ex Horm.). SNICS- SAGARPA, Universidad Autónoma Chapingo. http://www.chapingo.mx

Pickersgill, B. (1971). Relationships between weedy and cultivated forms in some species of chili peppers (Genus Capsicum). Society for the Study of Evolution, 25(4), 683-691.

Piotto, F. A., Batagin-Piotto, K. D., Almeida, M. de, \& Oliveira, G. C. X. (2013). Interspecific xenia and metaxenia in seeds and fruits of tomato. Scientia Agricola, 70(2), 102-107. https://doi.org/10.1590/\$010390162013000200007
Rodrigues, Eliana. (2006). Plants and animals utilized as medicines in the Jaú National Park (JNP), Brazilian Amazon. Phytotherapy Research, 20(5), 378-391. https://doi.org/10.1002/ptr.1866

Rodrigues, Eliseu, Rockenbach, I. I., Cataneo, C., Gonzaga, L. V., Chaves, E. S., \& Fett, R. (2009). Minerais e acidos graxos essenciais da fruta exótica Physalis peruviana L. Ciencia $e$ Tecnologia de Alimentos, 29(3), 642645. https://doi.org/10.1590/S010120612009000300029

Rukmi, K., \& Waluyo, B. (2019). Keragaman genetik aksesi ciplukan (Physalis sp.) berdasarkan karakter morfologi dan agronomi. Jurnal Produksi Tanaman, 7(2), 209-219.

Sadiyah, H., Ashari, S., Waluyo, B., \& Soegianto, A. (2021). Genetic diversity and relationship of husk tomato (Physalis spp.) from East Java Province revealed by SSR markers. Biodiversitas Journal of Biological Diversity, 22(1), 184-192. https://doi.org/10.13057/biodiv/d22 0124

Sadiyah, H., Soegianto, A., Waluyo, B., \& Ashari, S. (2020). Short Communication: Preliminary characterization of groundcherry (Physalis angulata) from East Java Province, Indonesia based on morpho-agronomic traits. Biodiversitas Journal of Biological Diversity, 21(2), 759-769. https://doi.org/10.13057/biodiv/d21 0244

Sahagún-castellanos, J. (1999). Heterosis intravarietal en tomate de cáscara ( Physalis ixocarpa Brot .). Revista Chapingo Serie Horticultura, 4(1), 3137.

Salgado, E. R., \& Arana, G. V. (2014). Physalis angulata L. (Bolsa mullaca): a review of its traditional uses, chemistry and pharmacology. Boletin Latinoamericano Caribe Plantas Medicinales Aromaticas, 12(5), 431- 
445.

Setiawati, T., Kurniawan, A., Supriatun, T., \& Karyono. (2016). Persilangan interspesifik Ipomea batatas Lam. dengan I. trifida (H.B.K.) G. Don. berumbi asal Citatah, Jawa Barat. Kebun Raya Bogor LIPI, 19(1), 11-20.

Shandila, P., Zanetta, C. U., \& Waluyo, B. (2019). Pengukuran keragaman dan identifikasi aksesi ciplukan (cape gooseberry: Physalis peruviana L.) hasil seleksi galur murni sebagai buah eksotis. Prosiding Seminar Nasional 'Pembangunan Pertanian Indonesia Dalam Memperkuat Lumbung Pangan, Fundamental Ekonomi, Dan Daya Saing Global', 1160-1168.

Sharma, N., Bano, A., Dhaliwal, H. S., \& Sharma, V. (2015). Perspectives and possibilities of indian species of genus Physalis (L.). European Journal of Pharmaceutical and Medical Research, 2(2), 326-353.

Siemens, J. (2002). Interspecific hybridisation between wild relatives and Brassica napus to introduce new resistance traits into the oilseed rape gene pool. Czech Journal of Genetics and Plant Breeding, 38(3-4), 155157.

Syukur, M., Sujiprihati, S., \& Yunianti, R. (2018). Teknik Pemuliaan Tanaman (edisi revisi). Penebar Swadaya.

Trevisani, N., Schmit, R., Beck, M., Guidolin, A. F., \& Coimbra, J. L. M. (2016). Selection of fisális populations for hibridizations, based on fruit traits. Revista Brasileira de Fruticultura, 38(2), e-568. https://doi.org/10.1590/010029452016568

UPOV. (2005). Guidelines for The Conduct of Tests for Distinctness, Uniformity and Stability: Husk Tomato (Physalis phyladelphica Lam., Physalis ixocarpa Brot., Physalis pruinosa L., and
Physalis angulata L.) (Draft). In International union for the protection of new varieties of plants. Guidelines for the Conduct of Tests for Distinctness, Uniformity, and Stability. International union for the protection of new varieties of plants.

Waluyo, B., Zanetta, C. U., \& Haesaert, G. (2019). Assessment of variability, heritability and divergence of ciplukan [cutleaf ground cherry: (Physalis angulata L.)] to increase exotic fruit genetic capacity in Indonesia. Proceedings of the Emerging Challenges and Opportunities in Horticulture Supporting Sustainable Development Goals - ISH 2018 (Kuta, Bali, Indonesia 27-30 November 2018), 89-98. https://www.filodiritto.com/node/36 464

Widyaelina, E., \& Waluyo, B. (2019). Seleksi tomatillo (Physalis ixocarpa Brot. ex Hornem) untuk hibridisasi berdasarkan karakter morfologi. Jurnal Pertanian Terpadu, 7(2), 152165.

Yildiz, G., Izli, N., Unal, H., \& Uylaser, V. (2015). Physical and chemical characteristics of goldenberry fruit (Physalis peruviana L.). Journal of Food Science and Technology, 52(4). https://doi.org/10.1007/s13197-0141280-3

Zanetta, C. U., Waluyo, B., \& Haesaert, G. (2019). Exploitation of variability and genetic divergence of tomatillo (Physalis ixocarpa Brot) as tool for further breeding. Proceedings of the Emerging Challenges and Opportunities in Horticulture Supporting Sustainable Development Goals - ISH 2018 (Kuta, Bali, Indonesia 27-30 November 2018), 58-65. https://www.filodiritto.com/node/36 464 